\title{
Pembelajaran Daring pada Materi Teks Laporan Hasil Observasi
}

\author{
Sandra Julia* \\ E- mail : sandra.juloa0582@student.unri.ac .id \\ Program Studi Pendidikan Bahasa dan Sasstra Indonesia, Universitas Riau
}

\section{Pengantar}

Pembelajaran bahasa Indonesia merupakan serangkaian aktivitas yang dilakukan siswa untuk mencapai keterampilan berbahasa tertentu. Menurut Abidin (2012: 82) pembelajaran bahasa adalah pembelajaran yang harus mampu menyajikan sejumlah stimulus yang baik guna menghasilkan respon yang berkualitas serta telah mengeluarkan respon tersebut. Pembelajaran bahasa Indonesia selalu menggunakan teks untuk sarana pembelajaran sejalan pula dengan Kurikulum 2013 yakni pembelajaran berbasis teks.

Pembelajaran berbasis teks menuntut siswa menggunakan bahasa tidak hanya sarana komunikasi, tetapi juga sebagai sarana untuk mengembangkan kemampuan berfikir. Menurut Ramadania (2016 : 228) dalam pembelajaran berbasis teks, yakni bahasa Indonesia diajarkan bukan sekadar pengetahuan bahasa, melainkan sebagai teks yang mengemban fungsi untuk menjadi sumber aktualisasi diri penggunanya pada konteks sosial, budaya, dan akademis.

Teks laporan hasil observasi adalah jenis teks yang menyajikan informasi umum mengenai sesuatu setelah diadakannya investigasi penelitian. Jenis teks ini biasanya berisi fakta-fakta tentang suatu hal, deskripsi dan informasi tentang kebiasaan dan kualitas suatu hal yang dapat dibuktikan secara ilmiah dalam teks laporan hasil observasi. Teks laporan hasil observasi adalah teks yang menyampaikan informasi tentang sesuatu yang faktual, disajikan apa adanya teks yang menyampaikan informasi tentang sesuatu apa adanya sebagai hasil pengamatan dan analisis secara sistematis (Anderson dalam Azizi 2017:11). Jadi, pada dasarnya teks laporan hasil observasi adalah teks yang lahir dari hasil pengamatan yang kemudian dituangkan menggunakan bahasa yang sistematis. Dalam hal ini, guru harus bisa memfasilitasi proses pembelajaran untuk mempermudah jalannya siswa mencapai tujuan pembelajaran.

Pada masa pandemi covid-19 ini, memaksa guru maupun siswa untuk melakukan pembelajaran secara online, dimana pembelajarannya tanpa tatap muka secara langsung. Ini mengakibatkan guru untuk berfikir lebih keras dan kreatif dalam melakukan pembelajarannya agar siswa tetap dapat memahami materi yang diberikan secara online, dan juga memaksa siswa untuk tetap lebih fokus untuk memahami materi yang diberikan walaupun secara online.

Jumlah mata pelajaran yang diberikan adalah berjumlah 15 mata pelajaran, media yang digunakan dalam pembelajarannya selama masa pandemi ini berupa classroom, meet google dan wa grup. Sedangkan khusus pembelajar Bahasa Indonesia online media yang digunakan adalah classroom,wa grup dan YouTube sebagai medianya sendiri untuk referensi lebih banyak. 
Kesulitan yang dihadapi saat melakukan pembelajaran secara online, menurut siswa terkadang kurang mengerti apa yang guru sampaikan, mata suka perih karena pagi ${ }^{2}$ harus daring menggunakan HP, kuota nya boros mengakibatkan uang jajan menjadi berkurang dan masalah yang utama pada masa pandemi ini ia tidak bisa bertemu temen secara langsung jadi berkurangnya motivasi dan berkomunikasi secara langsung.

Tetapi,siswa juga merasa diuntungkan dan senang dengan adanya pembelajaran daring ini, karena ia bisa belajar aplikasi-aplikasi pembelajaran yang belum ia gunakan bahkan belum tahu sebelumnya. Walaupun kebanyakan kurang senengnya,,dibanding senengnya karena kesulitan yang hadapi siswa. 


\section{Tindakan yang Dilakukan}

\section{a. Pendidik}

Pendidik dalam ranah ini kita kenal dengan sebutan guru. Guru adalahsosok yang begitu dihormati karena memiliki tugas yang cukup besar terhadap keberhasilan kegiatan pembelajaran di sekolah. Guru sangat berperan dalam membantu tercapainya suatu pembelajaran yang unik dan menyenangkan, mampu membuat inovasi baru dalam sebuah pembelajaran dengan tujuan mencapai serta meningkatkan kemampuan dan karakter yang optimal, serta guru memiliki tanggung jawab dalam membimbing dan membina peserta didik untuk selalu berkreasi dalam proses belajar mengajar (Hamid, 2017).

Dalam sebuah pembelajaran guru dituntut untuk memberikan sebuah pemahaman atau pencerahan terhadap inovasi atau sesuatu hal yang akan ia lakukan. Guru ialah insan yang mempunyai keahlian dalam mencurahkan suatu uraian dan pencerahan baik etika maupun aspek kerohanian kepada setiap orang (Zulhafizh, 2013). Dengan ini guru dapat memberikan pemahaman serta pencerahan terlebih dahulu terkait sebuah inovasi pembelajaran yang akan dijalankan agar hasil yang didapatkan nantinya baik dan tentunya tidak melanggar etika dan spiritual seorang peserta didik.

Dalam proses pembelajaran guru juga dapat mengolaborasikan antara ide atau inovasinya, namun hal itu harus seimbang dengan sikap kepribadian dan sikap profesional. Di mana diungkapkan oleh Mulyasa (2005) bahwa guru yang profesional ialah guru yang memiliki: (1) Kompetensi pedagogik, yaitu kemampuan yang berkenaan dengan sebuah pemahaman peserta didik dan pengelola pembelajaran yang mendidik, yang mencakup kemampuan perancangan dan pelaksanaan pembelajaran, evaluasi terhadap hasil belajar, dan pengembangan siswa untuk mengaktualisasikan berbagai potensi yang berawal dari inovasi yang dimilikinya. (2) Kompetensi kepribadian, yaitu kemampuan secara individu yang mencerminkan kepribadian yang dewasa, mantap, arif, stabil, dan juga berwibawa dalam segala hal. (3) Kompetensi sosial, yakni berkenaan dengan kemampuan guru sebagai bagian dari masyarakat untuk berkomunikasi secara efektif dengan siswa, warga sekolah dan juga masyarakat, baik dalam media secara langsung ataupun dalam media sosial.

Perihal di atas pula tidak dapat terlepas begitu saja dari seluruh kompetensi yang dipunya yakni suatu motivasi yang diberikan oleh guru dalam melakukan aktivitas pendidikan. Sehingga guru dalam menjalankan pembelajaran yang bernuansa berbeda, siswa akan terus termotivasi dengan segala keadaan, sebab motivasi dapat mendorong siswa untuk menerapkan pembelajaran guna mendapatkan hasil dari proses belajarnya itu dan tentunya siswa akan berusaha mencari cara untuk menerapkan pembelajaran, baik itu menulis ataupun yang sedang dipelajarinya. Motivasi belajar sangat diperlukan dalam belajar, motivasi ini adalah penggerak bagi siswa dalam belajar guna memperoleh hasil yang maksimal (Zulhafizh, Atmazaki, \& Syahrul, 2013). Seperti halnya dalam memotivasi serta memberikan inovasi terhadap siswa mengenai pembelajaranyang memanfaatkan media sosial, seperti media whatsapp, classroom, grup whatsapp, youtube dan zoom.

Sedangkan menurut Wardana (2013) guru atau pendidik adalah komponen yang paling menentukan dalam sistem pembelajaran secara keseluruhan, yang harus mendapat perhatian sentral, pertama, dan utama, serta sebagai sumber daya manusia yang menjadi perencanaan, pelaku dan penentu tercapainya tujuansebuah pendidikan. 


\section{b. Peserta Didik}

Peserta didik adalah manusia seutuhnya yang berupaya mengasah kemampuan agar lebih potensial dengan bantuan atau dorongan pendidik atau orang dewasa. Secara terminologi, peserta didik berarti anak didik atau individu yang mengalami perubahan dan perkembangan yang mengalami proses pembelajaran yang pada umumnya memiliki kebutuhan-kebutuhan wajib dan mendasar yang harus dipenuhi dan tidak bisa dihindarkan dalam artian diberi didikan atau bimbingan oleh seseorang yang lebih dewasa darinya seperti guru ataupun sosok yang lainnya (Devianti \& Sari, 2020; Harahap, 2016). Menurut Danim dalam Agustina (2018) peserta didik adalah bentuk nama secara sah yang sudah dilegalkan oleh badan hukum terutama badan hukum kependidikan yang mengubah atau menggantikan sebutan murid, siswa atau pelajar. Namun, sebutan tersebut tidak menjadi hal yang sama persis terjadi di dalam dunia pendidikan. Karena, secara konvensional sebutan yang lainnya akan terucap atau tersampaikan dalam proses pendidikan itu sendiri. Di dalam UU No. 20 Tahun 2003 Tentang Sistem Nasional Pendidikan, peserta didik dapat diartikan seseorang yang selalu mengembangkan kemampuan dirinya baik dalam proses pembelajaran formal di sekolah ataupun nonformal, dan pada jenjang ataupun jenis pendidikan tertentu. Hal ini peserta didik diberi kebebasan oleh pendidik dalam mengeksplorasikan sebuah pembelajaran yang tentunya memanfaatkan kecanggihan sebuah teknologi seperti berbagai aplikasi media sosial untuk melatih tingkat pembelajaran, motivasi, serta daya kreativitas.

\section{c. Diklat Pembelajran Daring pada Materi Teks Laporan Hasil Observasi}

Pembelajaran menulis teks laporan hasil observasi merupakan salah satu materi pembelajaran yang bisa meningkatkan keterampilan menulis pada siswa. Teks laporan hasil observasi adalah teks yang ditulis berdasarkan pengamatan langsung. Hal ini sependapat dengan Kosasih (2013: 36), teks laporan hasil observasi adalah teks yang memuat kejadian fakta yang diperoleh melalui hasil pengamatan secara langsung. Teks laporan hasil observasi memberikan informasi secara umum kepada pembacanya. Pengamatan atau observasi dilakukan oleh pengamat dengan cara terjun langsung ke lapangan untuk mengetahui informasi yang aktual.Penulisan teks laporan hasil observasi bisa dijadikan sebagai bahan latihanmenulis pada siswa.

\section{Langkah-Langkah Menulis Teks Laporan Hasil Observasi}

Secara umum, menulis teks laporan hasil observasi terdiri dari beberapa tahap. Tahapan tersebut sebagai berikut:

1). Menentukan objek dan melakukan kegiatan observasi.

Hal yang dilakukan yaitu sebagai berikut:

a. Melakukan survey ke tempat yang diinginkan.

b. Menemui narasumber jika dibutuhkan sebagai penguat data.

c. Mencatat informasi yang diperoleh sesuai tujuan observasi. 
2) Menulis kerangka teks laporan hasil observasi

Setelah menentukan objek dan memperoleh data, langkah selanjutnya yaitu menyusun berpikir laporan. Saat menyusun kerangka laporan harus sesuai kaidah yang ditentukan, seperti pernyataan umum, deskripsi bagian, dan simpulan.

3) Mengembangkan kerangka laporan

Tahap terakhir yaitu mengembangkan kerangka laporan menjadi laporan yang lengkap dan utuh. Dalam mengembangkan laporan harus sesuai kaidah kebahasaan dan harus memerhatikan penggunaan ejaan, bahasa baku, dan tanda baca.

Berdasarkan hasil observasi di atas, langkah utama pembelajaran sesuai dengan model pembelajaran problem based learning yang dilakukan guru secara berurutan dimulai dari menyampaikan salam dan mengecek kehadiran siswa, memberikan apersepsi terkait dengan pengalaman nyata yang dialami guru, menyampaikan indikator dan tujuan pembelajaran, menyampaikan rencana kegiatan pembelajaran, memberikan konsep dasar yang diperlukan dalam pembelajaran, memancing siswa untuk menggunakan buku pelajaran atau sumber lain, memberikan kesempatan kepada siswa untuk bertanya mengenai konsep dasar, petunjuk, referensi, atau link dan skillyang belum dipahami, membagi siswa ke dalam beberapa kelompok, menyampaikan skenario atau permasalahan, membimbing siswa dalam mencari informasi dan mengembangkan pemahaman yang relevan dengan permasalahan, membimbing siswa dalam menuliskan laporan sesuai dengan permasalahan dan data pendukung yang ada, membimbing siswa untuk berdiskusi dalam kelompoknya, melakukan penilaian terhadap aktivitas pembelajaran berbicara dalam diskusi siswa, memberikan umpan balik terhadap kegiatan pembelajaran, menyimpulkan hasil pembelajaran yang telah dilaksanakan serta mengevaluasi pembelajaran, memberikan penghargaan terhadap usaha yang dilakukan siswa dalam belajar berbicara, mengakhiri pembelajaran dengan mengucapkan salam.

Berdasarkan langkah-langkah pembelajaran yang diterapkan oleh guru dapat dikomentari sebagai berikut.Yang pertama, pembelajaran dengan model pembelajaran problem based learning yang telah diterapkan guru telah memenuhi standard pelaksanaan. Sintak untuk penerapan model problem based learning telah terpenuhi, seperti langkah-langkah penerapannya.

Dalam problem basedl, standard pembelajaran dilaksanakan sesuai dengan sintak sebagaimana tabel di atas. Standardnya, model problem based learning terdiri atas empat fase, yang dimulai dari fase orientasi dan organisasi, investigasi, pengembangan dan presentasi, sampai dengan analisis dan evaluasi. Keseluruhan sintak standard ini memiliki langkah-langkahnya tersendiri. Jika dikaitkan dengan penerapan problem based learning oleh guru dalam pembelajaran menulis teks laporan hasil observasi terhadap siswa kelas X. IIS 1 SMAN, seluruh sintak pembelajaran telah terpenuhi. Pemenuhan sintak standard tersebut tercermin dalam seluruh langkah pembelajaran yang dilakukan guru selama pembelajaran berlangsung.

Dalam 17 langkah pembelajaran tersebut, guru telah memeuhi fase-fase pembelajaran dengan metode Problem Based Learning, yakni dengan memulai pembelajaran dengan fase orientasi dan organisasi, dilanjutkan dengan investigasi, disusul dengan fase pengembangan dan presentasi, dan diakhiri dengan fase analisis dan evaluasi. Bertolak dari fase-fase standard tersebut, bisa disimpulkan bahwa guru telah mampu menerapkan model problem based learning sesuai dengan sintaknya serta mampu menerapkan langkah-langkah pembelajarannya secara tepat dan efisien. Penerapan model problem based learning pada siswa kelas X. IIS 1 SMAN tergolong baik dan berhasil jika dilihat dari pemenuhan kriteria keterlaksanaan langkah pembelajaran dan juga skor yang dihasilkan siswa selama 
pembelajaran berlangsung. Pada pembelajaran di kelas X. IIS 1 SMAN, ada beberapa hal yang menjadi kunci keberhasilan keterlaksanaan model problem based learning dalam rangka menulis teks laporan hasil observasi sehingga metode problem based learning bisa diterapkan dengan baik. Hal-hal yang dimaksud akan dirinci sebagai berikut. Yang pertama, guru mampu merangsang rasa ingin tahu siswa dengan permasalahan yang dekat dan ada di sekitar siswa. Dalam model problem based learning, rangsangan awal terhadap fenomena yang akan dibahas sangatlah penting. Tanpa adanya rangsangan yang menarik, model problem based learning akan menjadi model pembelajaran yang membosankan bagi siswa, bahkan cenderung menimbulkan ketakutan akan materi yang dipelajari. Menurut Gino, dkk. (2000: 36-39) faktor yang memengaruhi keberhasilan pencapaian tujuan pembelajaran salah satunya adalah pemberian ransangan dan motivasi belajar.Menggunakan fenomena yang sering dilihat atau umum diketahui akan memudahkan siswa untuk menuliskannya dalam bentuk laporan hasil observasi. Mulyasa (2013: 1) mengatakan teks adalah ungkapan pikiran manusia yang di dalamnya ada situasi dan konteksyang dapat ditemukan oleh siswa di sekitar mereka terlebih ketika guru mampu mengarahkan dengan tepat.Dalam penerapannya, ketika memberikan apersepsi, misalnya, guru mampu memancing siswa dengan menggunakan alam sekitar siswa sebagai ilustrasinya.

\section{Sarana Pendukung}

Sarana adalah segala sesuatu yang bisa digunakan sebagai alat dalam mencapai tujuan atau maksud (Pusat Bahasa Kemdikbud, 2016). Sarana ini sama halnya dengan wadah yang merupakan arti dari sebuah media (Hamzah, 2015). Pendukung erat kaitannya dengan segala sesuatu yang harus ada dalam sebuah proses atau kegiatan. Sehingga sarana pendukung ini adalah segala sesuatu yang menjadi alat dalam menjalankan sebuah media untuk mencapai maksud atau tujuan tertentu. Dalam hal itu pembelajaran daring pada materi teks laporan hasil observasi tentunya harus memiliki sarana pendukung agar kegiatan tersebut dapat terlaksana dengan baik. Adapun sarana pendukung dalam pembelajaran daring pada materi teks hasil observasi sebagai berikut :

\section{a. google classroom}

Google Classroom adalah layanan gratis yang dikembangkan Google untuk sekolah yang ditujukan untuk menyederhanakan mendistribusikan, dan menilai tugas dengan cara tanpa kertas. Tujuan utamanya adalah merampingkan berbagi file antara siswa dan guru. Dengan menggunakan google classroom guru bisa membuat kelas maya, mengajak siswa gabung dalam kelas, memberikan informasi terkait proses KBM, memberikan materi ajar yang bisa dipelajari siswa baik berupa file paparan maupun video pembelajaran, memberikan tugas kepada siswa, membuat jadwal pengumpulan tugas dan lain.

\section{b. WhatsApp}

WhatsApp adalah aplikasi pesan instan untuk smartphone, jika dilihat dari fungsinya WhatsApp hampir sama dengan aplikasi SMS yang biasa Anda pergunakan di ponsel lama. Tetapi WhatsApp tidak menggunakan pulsa, melainkan data internet. Jadi, di aplikasi ini sobat tak perlu khawatir soal panjang pendeknya karakter. Tidak ada batasan, selama data internet sobat memadai. Meskipun merupakan aplikasi pesan instan, ada yang unik dari WhatsApp. Jadi, sistem pengenalan kontak, verifikasi dan pengiriman pesan tetap dilakukan melalui nomor ponsel yang sudah terlebih dahulu didaftarkan. Sebagai aplikasi pesan instan, WhatsApp memiliki peranan penting dalam berkomunikasi, baik untuk personal ataupun 
grup. Dengan WhatsApp, pengguna dapat berkirim pesan teks, foto, audio, video, dokumen, serta melakukan panggilan audio dan video.

\section{c. Google meet/zoom}

Google Meet (sebelumnya dikenal Hangouts Meet) adalah layanan komunikasi video yang dikembangkan oleh Google. Aplikasi ini merupakan salah satu dari dua Aplikasi yang nantinya akan mengganti Google Hangouts, yang lainnya adalah Google Chat. Apabila kegiatan meeting sudah selesai, atau kita hendak keluar dari kegiatan meeting, cukup klik tombol "tutup" pada bagian tengah layar, atau klik tombol "back" pada menu navigasi di bagian bawah layar smartphone android.

Zoom merupakan aplikasi yang menyediakan layanan konferensi jarak jauh dengan menggabungkan konferensi video, pertemuan online, obrolan, hingga kolaborasi seluler. Aplikasi ini banyak digunakan sebagai media komunikasi jarak jauh.

\section{d. Kuota Internet}

Paket data internet atau sering disebut dengan kuota internet menjadi sarana yang sangat mendukung demi tercapainya pembelajaran ini. Sebab, jika tidak ada kuota internet maka aktivitas pembelajaran menulis teks deskripsi tidak dapat berjalan, sebagian besar siswa tentunya menggunakan kuota internet demi menjalankan aplikasi yang ada di dalam handphone-nya tidak terkecuali media sosial instagram. Dengan adanya kuota internet ini guru dan para siswa dapat melaksanakan kegiatan pembelajaran tersebut tentu sebelumnya masing-masing siswa memiliki gawai dan berada dalam kondisi jaringan internet yang stabil.

\section{e. Jaringan Internet}

Internet adalah salah satu sarana yang sangat dibutuhkan dalam kehidupan seharihari. Bagaimana tidak? Internet menjadi wadah dalam mencari sebuah informasi atau menemukan berbagai hal yang ada di dalam perangkat lunak yang tersambung dengan koneksi internet. Khozaimi (2017) internet adalah sebuah sarana yang menjadi salah satu kebutuhan oleh para peserta didik saat ini, internet dapat membantu memperoleh informasi serta berbagai referensi. Jaringan internet menjadi pelengkap dalam berbagai sektor dan tidak terlepas dari berbagai aktivitas, terlebih pada saat ini yang dapat dijumpai hampir semua aplikasi, baik itu desktop, website, mobile, yang difungsikan dalam lapisan bidang, baik bidang pendidikan, bank, logistik, transportasi dan lain-lain (Rahman et al., 2020). Dalam (Pusat Bahasa Kemdikbud, 2016) internet adalah jaringan komunikasi elektronik yang mampu menghubungkan dan memberi fasilitas terhadap komputer agar terorganisasi melalui satelit atau telepon di seluruh dunia.

Dari beberapa pengertian di atas, maka sarana ini menjadi hal yang sangat mendukung adanya pembelajaran daring pada materi teks laporan hasil observasi menggunakan. Dengan ini sebuah aplikasi akan berjalan apabila memiliki koneksi atau jaringan yang cepat dan stabil. Sehingga, aktivitas pembelajaran itu dapat tercapai dengan baik.

\section{Tindakan Solutif}

Seorang pendidik atau guru dalam sebuah pembelajaran harus mampu dalam mengelola sebuah inovasi dan mampu dalam menciptakan sebuah solusi apabila inovasi yang dijalankan tidak berada pada tempatnya. Mustafa, Hermandra, \& Zulhafizh, (2019) seorang guru harus mampu 
menjadi pembuat solusi sekaligus pemecah masalah bagi dirinya dan juga peserta didiknya. Ketika suatu kendala atau halangan muncul saat proses belajar mengajar atau aktivitas yang sedang dilakukan, maka guru harus mampu bertindak dalam upaya mengatasi agar kegiatan menulis teks hasil observasi menggunakan media sosial tetap berjalan dengan baik. Perihal ini tidak dapat terlepas dari sebuah tindakan atau aksi solutif yang dapat dicoba oleh seorang guru ataupun siswa. Tindakan solutif tersebut antara lain:

a. Jika ada beberapa siswa yang tidak atau belum memiliki alat piranti digital seperti handphone maka setiap siswa dapat meminjam atau membeli perangkat tersebut. Jika masih tidak memungkinkan, siswa dapat menggunakan handphone orang tua masing-masing atau bisa juga berkunjung ke rumah teman sejawat untuk belajar bersama serta meminta tolong (meminjam) agar dapat menulis teks laporan hasil observasi yang nantinya diunggah ke media sosial, namun tetap mencantumkan nama pemilik atau pembuat teks, hal ini tentunya sudah diketahui oleh guru. Solusi yang dapat dilakukan oleh guru salah satunya adalah dengan membagi siswa dalam beberapa kelompok (Khasanah, 2018). Dengan hal ini dapat meminimalisir bagi siswa yang belum atau tidak memiliki handphone.

b. Jika ada sebagian siswa yang memiliki kendala dalam hal jaringan, sehingga tidak dapat memposting gambar serta caption teks hasil observasi. Maka tindakan solutif yang dapat dilakukan adalah siswa dapat mencari atau mengusahakan di mana sumber atau tempat adanya jaringan yang stabil.

c. Jika tidak adanya atau kurangnya kuota internet atau paket data maka siswa dapat membeli paket data internet atau meminta bantuan hostpot perangkat lain yang terhubung ke jaringan internet hal ini bisa teman, guru ataupun orang tua. Solusi lainnya adalah dengan mencari atau menggunakan WiFisekitar apabila jaringan tersebut terkoneksi dengan baik.

d. Jika aplikasi belum atau tidak terinstal/terunduh serta terkendala dalam mengoperasikannya maka solusinya guru memberikan arahan atau bimbingan untuk menginstal aplikasi tersebut di App Market atau Play Store di handphone masing-masing sesuai dengan keperluan dan dapat mempelajari cara menggunakannya atau mengoperasikannya dari berbagai macam sumber. Misalnya mencari di google, tutorial YouTube, melalui guru, orang tua, atau teman sejawat yang sudah mahir menggunakan dan atau mengoperasikanmedia sosial instagram tersebut.

e. Tindakan solutif yang lainnya adalah jika para siswa merasa sulit dalam mencurahkan ide yang akan dideskripsikan maka guru dapat memberikan sebuah media berupa gambar karena dalam media gambar ini siswa akan terbantu dan lebih mudah dalam mendeskripsikannya (Fajriyati, 2020).

\section{Simpulan}

Era digital yang terjadi saat ini harus ada usaha dari segenap lapisan masyarakat terutama bagi seorang guru dalam menyeimbangkan sebuah teknologi dan tentunya dapat menekan dampak negatif dan memperluas manfaat yang diberikan oleh kemajuan teknologi ini. Guru menjadi agen penggerak dalam memberikan dampak positif dari media sosial. Salah satunya adalah dengan memanfaatkan media sosial sebagai sarana pembelajaran. Sehingga dapat mengarahkan dan memberikan kesan belajar yang menarik kepada siswa. Salah satu upaya memanfaatkan media sosial adalah pembelajaran menulis Teks Hasil Observasi menggunakan berbagai aplikasi seperti classroom Googlemeet /zoom dan sebagainya. Hal ini akan menjadi sesuatu yang bermanfaat yakni menjalankan sebuah roda pembelajaran dengan kemajuan teknologi digital. 


\section{Referensi}

Abidin, Yunus. (2002). Pembelajaran Bahasa Berbasis Karakter. Bandung: PT Refika Aditama.

Adiatama, Nizar. (2015). Pembelajaran Cooperative Script dalam Meningkatkan Hasil Belajar IPS Siswa Kelas VII di MTsN Kediri 2. Skripsi. Prodi Pendidikan Pengetahuan Sosial, Fakultas Ilmu Tarbiyah dan Keguruan.

Azizi. (2017). Peningkatan Kemampuan Menulis Teks Laporan Hasil Observasi dengan Menggunakan Strategi Pemodelan pada Siswa Kelas VII C SMPN 15 Yogyakarta. Skripsi. Prodi Pendidikan Bahasa dan Sastra Indonesia, FBS, UNY.

Ikhsan.dkk. (2017). Pemanfaatan Lingkungan Sekolah Dasar Sebagai Sumber Belajar di SD Negeri 2 Teunom Aceh Jaya. Jurnal Ilmiah Pendidikan Sekolah Dasar,331.Kaban, Jaya. (2018). Penerapan Model Pembelajaran Cooperative Script dalam Meningkatkan Sikap kerja Sama pada Mata Pelajaran PAI Materi Ikhlas dan Pemaaf di SMP Swasta Ampera Batang Kuis. Skripsi.Prodi Pendidikan Agama Islam, UIN.

Kurniasih, Imas. (2015). Model Pembelajaran. Jakarta: Kata Pena.

Prasetyawati, P. (2019). Analisis Proses Pembelajaran Berbasis Student Centered Learning dalam Pendekatan Saintifik pada Mata Pelajaran Sejarah di SMAN SeKota Palu. ejournal katalogis, 131.Puryanti, Eris. (2015). Penerapan Metode Cooperative Script Terhadap Hasil Belajar Siswa Kelas V Mata Pelajaran SKI di Madrasah Ibtidaiyah Nurul Huda Kabupaten Oku Timur. Jurnal Raden Fatah, 308.

Ramadania, Farika. (2016). Konsep Bahasa Berbasis Teks pada Buku Ajar Kurikulum 2013. Jurnal Bahasa, Sastra, dan Pengajarannya, 228.

Sanjaya, Wina. (2008). Perencanaan dan Sistem Pembelajaran. Jakarta: Prenadamedia Group.

Sungkono. (2008). Pemilihan dan Penggunaan Media dalam Proses Pembelajaran. Jurnal UNY, 3.

Supriyadi. (2013). Evaluasi Pembelajaran Bahasa Indonesia. Gorontalo: UNG Press Gorontalo.

Susanto, Hadi. (2013, 05 21). Mode Cooperative Script. Retrieved 05 21, 2013, from Cooperative Web Site: http://bagawanabiyasa.wordpress.cm/2013/05/21/modelpembelajaran-cooperative script

Wendra, I Wayan. (2019). Buku Ajar Penulisan Karya Ilmiah. Singaraja: Jurusan Pendidikan Bahasa dan Sastra Indonesia, FBS, Undiksha.

Wijayanti. (2017). Efektivitas Penerapan Metode Cooperative Script Terhadap Memahami Teks Bacaan Mi Futuhiyyah Mraggen Demak . Skripsi. Fakultas Ilmu Tarbiyah dan Keguruan, Universitas Islam Negeri Walisongi Semarang. 
Wildan. (2017). Pelaksanaan Penilaian Autentik Aspek Pengetahuan Sikap, dan Keterampilan di Sekolah atau Madrasah. Jurnak Tatqif, 141.

Khozaimi, A. (2017). Implementasi Jaringan Point to Multipoint dengan Mikrotik RB 433 pada Jaringan Internet Asrama Mahasiswa Universitas Trunojoyo Madura. Jurnal Ilmiah NERO, 3(1), 53-60.

Mulyasa, E. (2005). Menjadi Guru Profesional. Bandung: PT Remaja Rosdakarya.

Mulyata, E. . S. (2005). Kupas Tuntas Telepon Seluler Anda. Yogyakarta: ANDI.

Mustafa, M. N., Hermandra, \& Zulhafizh. (2019). Teachers' Strategies to Design Media to Implement Communicative Leaning in Public Schools. Journal of Educational Sciences, 3(1), 13-24.

Pusat Bahasa Kemdikbud. (2016). Kamus Besar Bahasa Indonesia Edisi Kelima (KBBI V). Badan Pengembangan Dan Pembinaan Bahasa, Kementerian Pendidikan Dan Kebudayaan Republik Indonesia.

Rahman, T., Sumarna, \& Nurdin, H. (2020). Analisis Performa RouterOS MikroTik pada Jaringan Internet. JURNAL INOVTEK POLBENG, 5(1), 178-192.

Subana, M. (2009). Strategi Belajar Mengajar Bahasa Indonesia. Bandung: Pustaka Setia.

Sumarlam. (2003). Teori dan Praktik Analisis Wacana. Surakarta: Pustaka Cakra. UU No. 20 Tahun 2003 tentang Sistem Nasional Pendidikan.

Wardana, D. S. (2013). Motivasi Berprestasi dengan Kinerja Guru yang Sudah Disertifikasi. Jurnal Ilmiah Psikologi Terapan, 01(01), 98109.http://ejournal.umm.ac.id/index.php/jipt/article/viewFile/1361/1456

Zulhafizh. (2013). Guru: Profesi yang Tak Lekang Oleh Waktu. Dialog Interaktif Profesi Kependidikan, 1-11. https://doi.org/doi: 10.31219/osf.io/39sk6

Zulhafizh, Atmazaki, \& Syahrul, R. (2013). Kontribusi Sikap dan Motivasi Belajar Siswa Terhadap Hasil Belajar Bahasa Inodonesia. Jurnal Bahasa, Sastra dan Pembelajaran, 1(2), 13-28. 


\section{*Data Penulis}

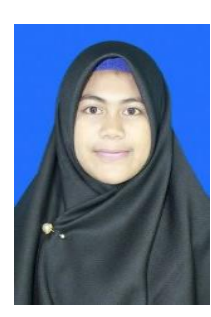

Sandra Julia, lahir Pulau Deras Kecamatan Pangean Kuantan Singingi, 21 Juli 2000. Ia tamat dari SMA Negeri 1 Pangean Kuantan Singingi pada tahun 2020 dan ia melanjutkan Studi pada Strata satu Jurusan Pendidikan Bahasa dan Sastra Indonesia FIKIP Universitas Riau melalui jalur SNMPTN (Seleksi Nasional Masuk Perguruan Tinggi Negeri)

Kontak :

Hp/Wa : 082278413407

Email : sandra.julia0582@student.unri.ac.id 